\title{
Laboratory experiments of point fixed glasses
}

MÁTÉ RÉNES - BSc student, BME Department of Construction Materials and Technologies - renesmate@gmail.com

ANDRÁs JAKAB - Ph.D. student, BME Department of Construction Materials and Technologies - jakab.andras@epito.bme.hu

KINGA NEHME - associate professor, University of Debrecen, Department of Civil Engineering - kpankhardt@yahoo.com

SALEM Georges NEHME - associate professor, head of laboratory, BME Department of Construction Materials and Technologies • sgnehme@yahoo.com

Érkezett: 2015. 03. 03. - Received: 03. 03. 2015. - http://dx.doi.org/10.14382/epitoanyag-jsbcm.2015.10

\section{Abstract}

The appearing of modern point fixed glass façade system was a big step in the development of the façade planning industry. However the application of steel surfaces has been constantly reducing in the last decades. Nowadays the façades consist of fast glass material including a small part of steel material. Safety is a primary requirement in every building material especially for glass materials. Laboratory experiments were carried out in the BME, Department of Construction Materials and Technologies to analyse the behaviour of point fixed glasses with pull-out test under quasi-static load. Strain, applied force and vertical displacement of the specimens were recorded. Single and laminated glasses were analysed with two different lengths. Based on the laboratory results, the authors recommend the most appropriate glass type for the point fixed glass façades. Keywords: glass, point fixing, pull-out test, glass façade

\section{Glass façades}

Glass is considered not only a household material but it is also applied in façades or in load bearing elements like columns, floors or even bridges. The application of this material started to be more popular in design, however, there is no Hungarian standards for design. Only examples, technical directives and unofficial methods are available. Engineers have to take into account the specific properties of glass during the design $[1,2]$.

This article focuses on the glass façades, especially on the mechanical connection between the glass and point fix connectors. The point fixed glass behaviour was studied under quasi-static load which characterises the wind pressure. Authors aim to develop an accurate and safe calculation method for the point fixed glass façade structures.

\section{Experimental procedure}

Laboratory experiments were carried out on point fixed glasses at the BME Department of Construction Materials and Technologies. Glass types and sizes are introduced in Table 1. Point fix connector was pulled out from the glass hence in the middle of the glass was located a bore hole with $20 \mathrm{~mm}$ diameter. The load bearing capacity (displacements, strain, loading force) was recorded during the loading. Strain gauges were applied near to the bore hole on the tensile side of the specimen in two different directions which were perpendicular to each other.

The test parameters of glass specimens were the followings:

- Constant parameters

- Rate of loading: $0.5 \mathrm{~mm} / \mathrm{min}$

- Width of the glasses $360 \mathrm{~mm}$

- Point fix connector: R50SSS

- Interlayer material: EVA, $0.38 \mathrm{~mm}$

- Test arrangement.

- Variable parameters

- Type of the glasses: Float, TVG (heat strengthened), ESG (tempered)

- Nominal thickness: single layer: $6 \mathrm{~mm}, 12 \mathrm{~mm}$, laminated: $2 \times 6 \mathrm{~mm}$

- Length of the glasses: $460 \mathrm{~mm}, 860 \mathrm{~mm}$.

\begin{tabular}{lllll}
\multirow{3}{3}{$\mathbf{3 6 0} \times \mathbf{4 6 0}$} & \multicolumn{1}{c}{ Float } & TVG & ESG \\
\cline { 2 - 5 } & $\mathbf{6}$ & 2 & 3 & 2 \\
\cline { 2 - 5 } $\mathbf{1 2}$ & 2 & - & 5 \\
\hline $\mathbf{6 . 6}$ & 1 & 2 & 2 \\
\cline { 2 - 5 } $\mathbf{6}$ & - & 2 & 2 \\
\cline { 2 - 5 } & $\mathbf{1 2}$ & 1 & - & 5 \\
\cline { 2 - 5 } & $\mathbf{6 . 6}$ & 2 & 4 & 2
\end{tabular}

Table 1 Amount and type of the glass specimens 1. táblázat Üveg próbatestek tulajdonságai

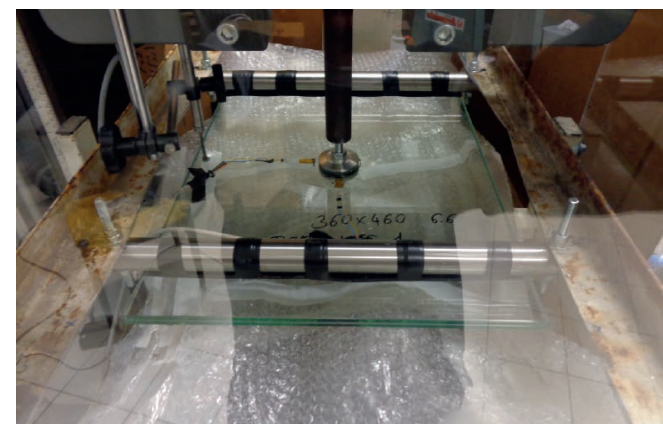

Fig. 1 Experimental test set-up

1. ábra Kísérleti elrendezés 


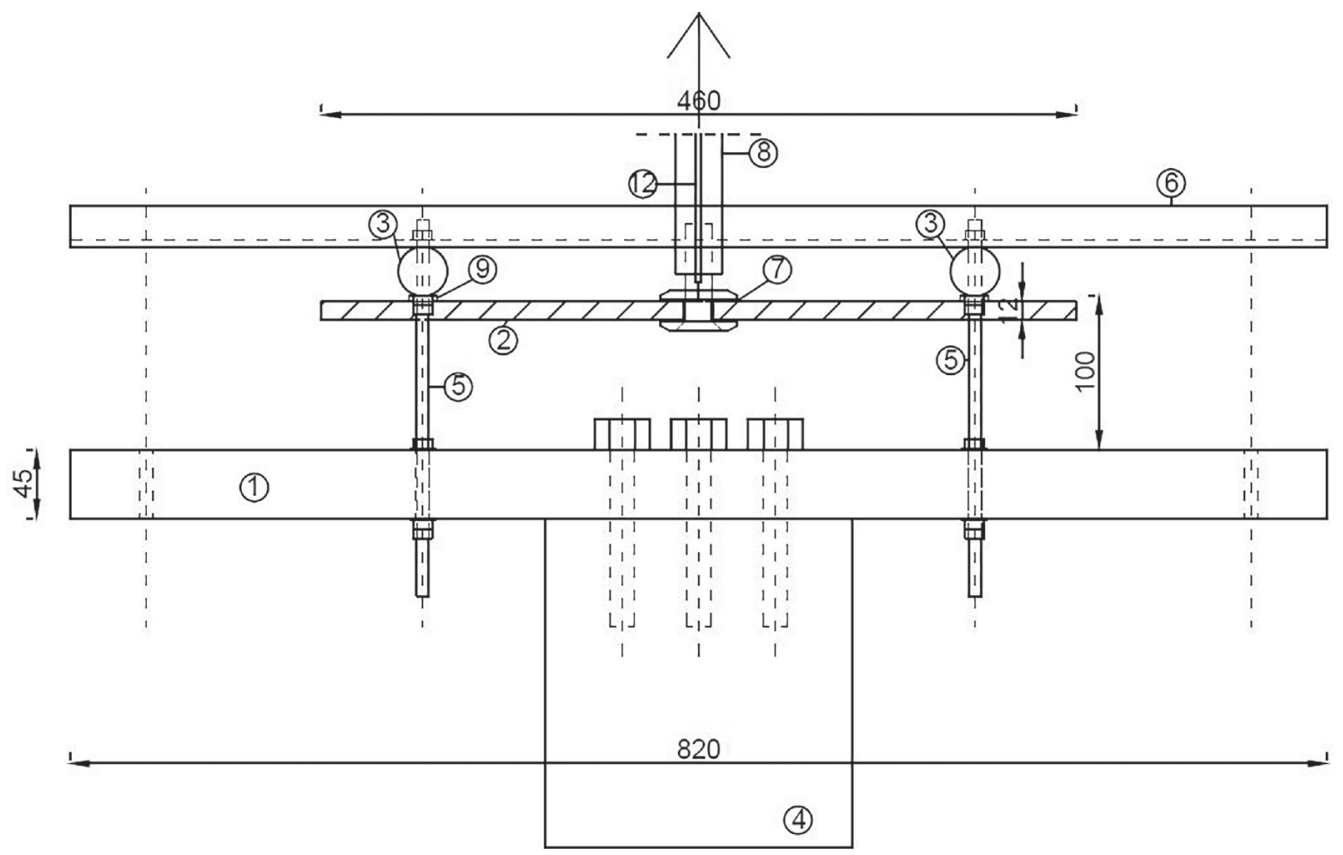

Fig. 2. Experimental test set-up. 1- Steel plate; 2- Glass specimen; 3- Steel cylinder supports; 4-Instron bottom cross-head, 5- Threaded rod; 6- Angle steelbar; 7. Point fix connector; 8- Threaded cylinder steel, 9- Rubber, 12-Displacement transducer

2. ábra Kísérleti elrendezés: 1-Acéllemez; 2- Üveglap; 3- Acélhenger megtámasztás; 4- Instron alsó keresztfej, 5- Menetes szár. 6- Szögacél; 7. Pontmegfogó szerelvény; 8- Menetes acélhenger, 9- Gumi, 12- Útadó

\subsection{The experimental test set-up}

The specimens were loaded with the use of Instron 5989 universal testing machine until fracture. In case of laminated glasses, the loading was sustained after the first fracture until the fracture of the second layer. The loading force and the displacement of the bore hole / point fix connector were recorded by Bluehill software. Vertical displacement transducer is shown in the right side of Fig. 1 which measured the edge deflections. It is located $10 \mathrm{~mm}$ offset from the edge of the specimen.

Fig. 1 and Fig. 2 show the experimental test set-up. Obviously the test set-up is a simply supported structure. A $5 \mathrm{~cm}$ thick steel plate was screwed to the bottom cross-head which had enough bending resistance. The cylinder steel supports were fixed to the steel plate in which they were adjustable into two different distances (360 and $720 \mathrm{~mm}$ ). The point fix connector was fixed into a stiff steel plate which was pulled by the Instron upper cross-head. The bore hole was positioned in the middle of the specimens. Hardness of Shore A 80 rubber was used for damping between the glass and steel. Beside this test set-up, the upper surface of a single layer glass was tensioned and the bottom surface was compressed.

Angle steel bar was applied in longitudinal direction to avoid the horizontal displacement of the supports. The ends of specimens are consoles (without loading) and the supports are perfectly hinged, hence the glass has free angular displacement around of the supports. The rate of loading was $0.5 \mathrm{~mm} / \mathrm{min}$ and the pull force was directed vertically and upwards.

Silicone rings separated the glasses from steel at the point fix connector, and plastic ring was applied around the screw in the bore hole, hence the glass was protected everywhere in the test set-up from the direct contact with the steel (Fig. 3). Displacements were recorded during the loading including the displacement due to the elastic rubber. Before starting test, a calibration measurement was performed and a stiff steel plate was applied instead of the glass specimen. After the loading of the glass specimens, the difference was extracted from the measured displacements. This method resulted the real displacements.
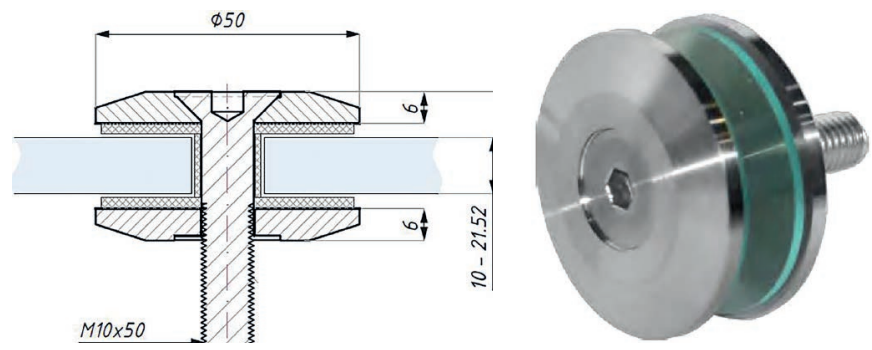

Fig. 3 Pont fix connector head - R50SSS, CDA [3]

3. ábra Pontmegfogó szerelvény - R50SSS, CDA [3]

\section{Experimental results and calculation}

\subsection{Edge work defects}

Cracks are formed in glass where the volume of edge defects and the level of tensile stress are higher [4]. Fig. 4 illustrates microscopic observations of $50 \times$ magnified regions in which the edge works and defects were analysed. Glass defects were obtained by the digital software of DinoCapture at the bore holes and edges.

The cracks were propagated from the defects of the bore holes until the glass edges. The load bearing capacity depends significantly from the type of glass failures (the depth of scratch, the amount, the density) [4]. It results even hundreds of Newton differences between the tested glass specimens. 


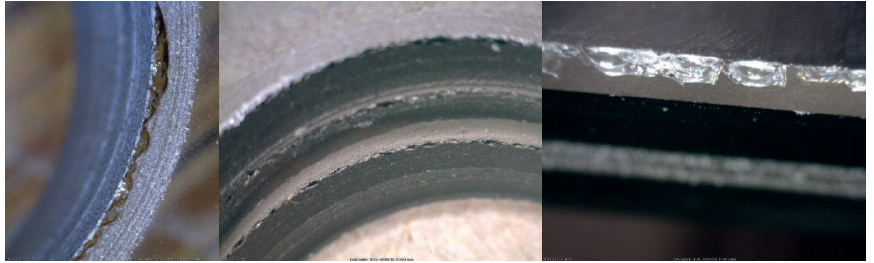

Fig. 4 Bore holes and edge defects at 50 $\times$ magnification

4. ábra Furatlyuk és él megmunkálási hiba 50 szeres nagyításban

\subsection{Results of load - displacement relationship}

The measured vertical displacements (at the bore holes and at the edge) are quite similar in case of $360 \times 860 \mathrm{~mm}$ single layer fully tempered glasses (large ones) with $6 \mathrm{~mm}$ thickness. There is no significant variation of that and even it is $0.26 \mathrm{~mm}$ at the fracture moment. However, this difference is significantly higher $(74 \%)$ in case of $360 \times 460$ $\mathrm{mm}$ single layer fully tempered glasses (smaller ones). This decrease can be obtained in case of $12 \mathrm{~mm}$ and laminated glasses consisted of $2 \times 6 \mathrm{~mm}$ fully tempered glass layers. This difference of the examined glasses is similar. In conclusion, the edge displacements of glasses decreased if the length of glass specimen are reduced comparing it to the displacements measured in bore hole regions (Fig. 5).
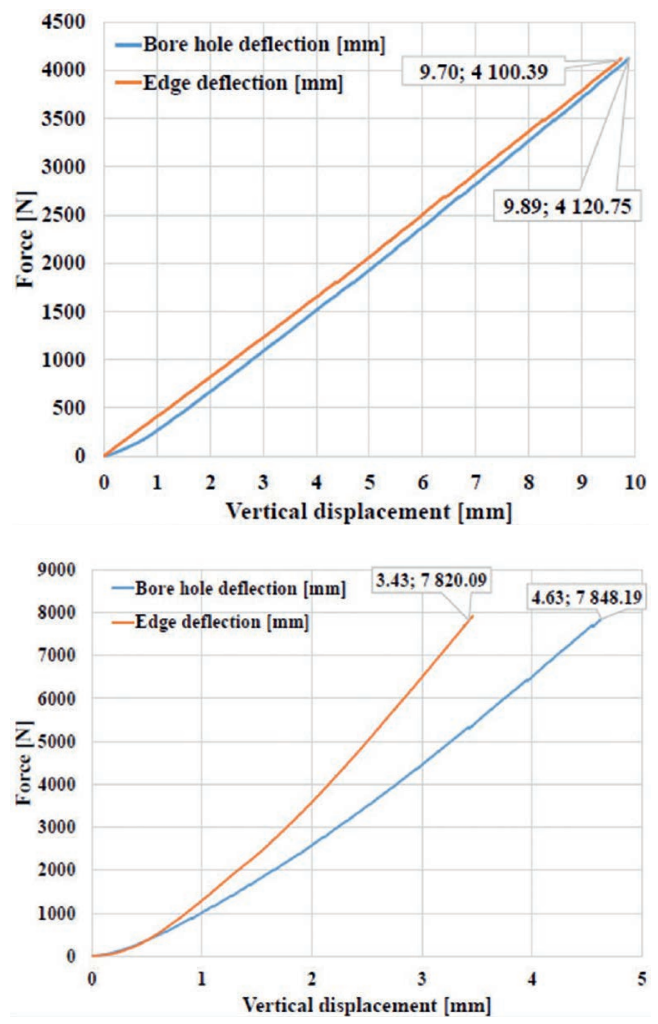

Fig. 5 Bore holes and edge displacements in case of $360 \times 860$ (left), $360 \times 460$ (right) sized fully tempered glasses, $12 \mathrm{~mm}$

5. ábra Pontmegfogó szerelvény (furatlyuk) és él menti elmozdulások összehasonlitása Edzett $12 \mathrm{~mm}$ vastag üvegek esetén bal: $360 \times 860$, jobb: $360 \times 460$

Fig. 6 introduces force and vertical displacements in case of fully tempered glasses with respect to different thicknesses and sizes of specimens. The highest displacements occurred in case of $6 \mathrm{~mm}$ thick single layer fully tempered glasses (5.59 $\mathrm{mm})$. In case of float glasses the maximal displacement was
$1.64 \mathrm{~mm}$ and it is $4.58 \mathrm{~mm}$ at TVG. The heat strengthening procedure can improve the load bearing capacity of the glass. The slope of the curve of $360 \times 460 \mathrm{~mm}$ laminated glasses after the fracture of the first glass layer is similar to that of same sized single layer glass consisted $6 \mathrm{~mm}$ glass. That of can be obtained in case of larger sized glasses as well. It means that the fractured glass layer has no significant load bearing function in the laminated glass.

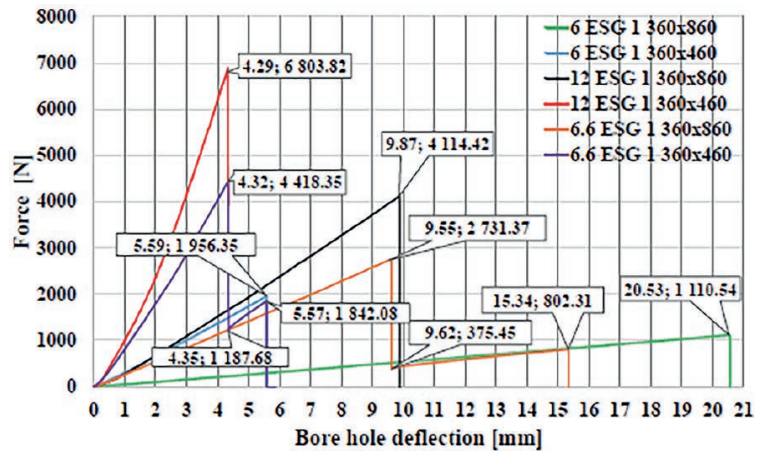

Fig. 6 Load and vertical displacements in case of fully tempered glasses 6. ábra Edzett üveglapok terhelö erö és függöleges elmozdulás diagramon

\subsection{Finite element model}

A finite element model was created to analyse the laboratory results. In the future studies, the authors plan to formulate a more accurate model where the influence of damping materials (rubbers, silicon) is going to be taken into account as well.

The vertical displacements of the bore hole and the edge point were different based on the finite element results of small specimen $(360 \times 460 \mathrm{~mm})$. However, this difference was not obtained in case of the larger size specimens $(360 \times 860 \mathrm{~mm})$ (Fig. 7). The mean displacement differences of the model and experimental values are introduced in the Table 2.
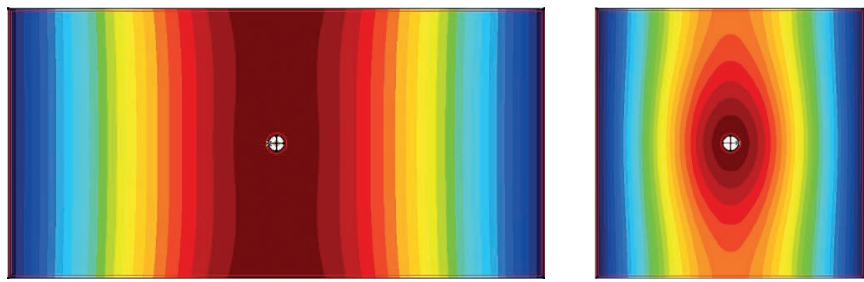

Fig. 7 Left: $6 \mathrm{~mm}, 360 \times 860 \mathrm{~mm}$ glass table deformation. Right: $6 \mathrm{~mm}, 360 \times 460 \mathrm{~mm}$ glass table deformation

7. ábra Bal kép: 6 mm-es nagyméretü tábla elmozdulása, jobb kép: 6 mm-es kisméretü tábla elmozdulása

\begin{tabular}{|c|c|c|}
\hline & \multicolumn{2}{|c|}{$360 \times 460 \mathrm{~mm}, 6 \mathrm{~mm}$ thick ESG } \\
\hline & $\begin{array}{l}\text { Model values } \\
\text { [mm] }\end{array}$ & $\begin{array}{l}\text { Experimental } \\
\text { values [mm] }\end{array}$ \\
\hline Deflection at bore hole & 5.64 & 5.6 \\
\hline \multirow[t]{3}{*}{ Edge deflection } & 4.54 & 4.6 \\
\hline & \multicolumn{2}{|c|}{$360 \times 860 \mathrm{~mm}, 6 \mathrm{~mm}$ thick ESG } \\
\hline & $\begin{array}{l}\text { Model values } \\
{[\mathrm{mm}]}\end{array}$ & $\begin{array}{l}\text { Experimental } \\
\text { values [mm] }\end{array}$ \\
\hline Deflection at bore hole & 20.33 & 20.34 \\
\hline Edge deflection & 20.27 & 20.29 \\
\hline
\end{tabular}

Table 2 Comparing the model and the laboratory results 2. táblázat FEM és laboratóriumi eredmények összehasonlítása 


\section{Conclusions}

Laboratory experiments were carried out on point fixed glasses. The behaviour of glasses was examined by pull-out test. Cracks are formed from the bore holes based on the laboratory experiments. The edge deflection of the glass depends on the length of specimen based on the force - vertical displacement diagrams. The difference between the edge and bore holes displacements were influenced by the sizes of the glass specimen.

In conclusion, if the glass plates were loaded in a larger area (of $360 \times 860 \mathrm{~mm}$ ), than two or three times higher displacements occurred and the load bearing capacity decreased by $50 \%$ like in the case of smaller $360 \times 460 \mathrm{~mm}$ glass plates. The load bearing capacity of the tested glasses depends on the level of heat strengthening (TVG/ESG).

A finite element model was created to analyse the laboratory results. The differences between displacements measured in edge and bore holes regions decreased with the increase of size of glasses from $360 \times 460 \mathrm{~mm}$ up to size of $360 \times 860 \mathrm{~mm}$.

The fully tempered and heat strengthened glasses are the most applicable glasses for use in glass façade according to the results in aspect of the safety and load bearing capacity. It should be mentioned that in case of using only tempered glass layers the glass panes do not have residual load bearing capacity. The Young's modulus of glasses is not affected by heat treatment based on the laboratory results.

\section{Acknowledgements}

Authors express their gratitude to Rákosy Glass Ltd. for providing the glass specimens. Authors are thankful to the laboratory of BME Department of Construction Materials and Technologies for the experiments and personally to Struktúra
Ltd. András Eipl, Abdulkader El Mir and István Vági for their technical support and advices.

References

[1] Pankhardt, K. (2012): Load Bearing Glasses. Testing of Construction Glasses. Lap Lambert, ISBN 9783847321910

[2] Jakab, A. - Nehme, K. - Nehme, S. G. (2014): Centrally Loading of Glass Columns, Proceedings of ÉPKO 2014 Conference, pp. 118-121.

[3] CDA Products Catalogue 2014-2015, $171 \mathrm{p}$.

[4] Pankhardt, K. - Balázs, G. L. (2010): Study of Edge Strength of Load Bearing Glasses, Építőanyag Vol. 62, No. 1, pp. 15-22. http://dx.doi.org/10.14382/epitoanyag-jsbcm.2010.4

\section{$\underline{\text { Ref.: }}$}

Rénes, Máté - Jakab, András - Nehme, Kinga - Nehme, Salem Georges: Laboratory experiments of point fixed glasses Építőanyag - Journal of Silicate Based and Composite Materials, Vol. 67, No. 2 (2015), 62-65. p. http://dx.doi.org/10.14382/epitoanyag-jsbcm.2015.10

\section{Pontmegfogású üvegek laboratóriumi vizsgálata}

A modern pontmegfogású üveghomlokzati rendszerek megjelenése nagy újítás volt a korábbi strukturális homlokzatképzésekhez képest. A homlokzati szerkezetekhez felhasznált acél felületek mennyisége jelentôsen lecsökkent az elmúlt évtizedekben. A BME Építōanyagok és Magasépítés Tanszék laboratóriumában kísérleteket végeztünk, ahol pontmegfogású üveghomlokzatok pontmegfogó szerelvény kiszakítását vizsgáltuk a felületre merôlegesen, reprezentálva egy pontmegfogó környezetében az üveg viselkedését. Kísérleteinkben mértük az üveglapok elmozdulását, alakváltozását és a felvett erôt. A kísérleti eredményeket monolitikus és többrétegú üvegek esetében is kiértékeltük. Az eredmények alapján megállapításokat tettünk, milyen típusú üvegek alkalmazása a legmegfelelő́bb a homlokzatot érố igénybevételek elviselésére.

Kulcsszavak: üveg, pontmegfogás, kihúzó vizsgálat, üveg homlokzat

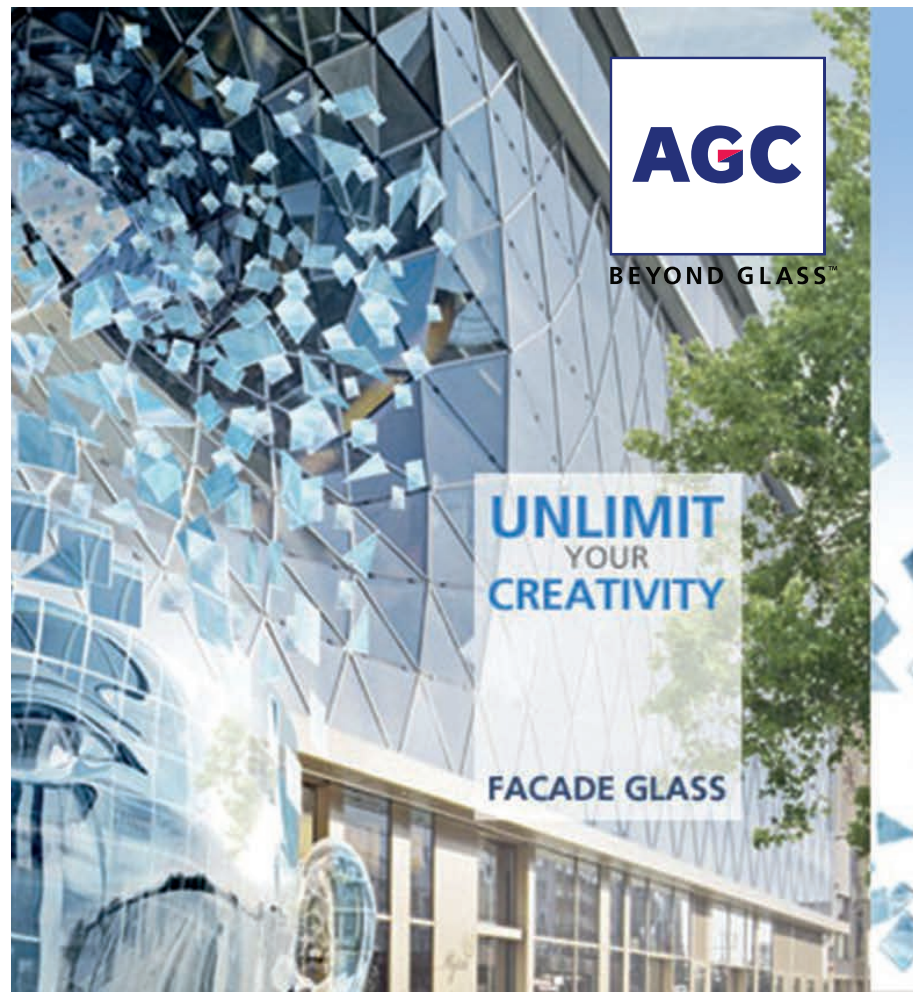

\section{Solutions for architects and facade builders}

AGC solutions have been developed to meet every conceivable need of facade builders and architects managing large-scale glass projects.

AGC has a wide range of products to meet the needs of building professionals with regard to vision glasses, spandrels and fitting solutions.

\section{Glassiled}

Glassiled-Facades is

a laminated glass with

embedded light-emitting

diodes (LEDs).

Structural duo +

Thanks to its new composite

materials, Structura Duo+ is

an ecological and

ecoñomical solution

\section{Thermobel Store}

Thanks to its integrated blinds,

Thermobel Store gives you constant, optimal control over light levels...

\section{Thermobel SunEwat}

SunEwat is laminated safety glass with photovoltaic cells encapsulated between two panes of glass...

\section{www.yourglass.com}

